\title{
Obesity, diabetes mellitus, and cancer
}

\author{
Wouter W de Herder and Charis Eng ${ }^{1}$
}

Section of Endocrinology, Department of Internal Medicine, Erasmus MC, 's Gravendijkwal 230, 3015 CE Rotterdam, The Netherlands

${ }^{1}$ Cleveland Clinic Genomic Medicine Institute, 9500 Euclid Avenue, Mailstop NE-50 (Rm NE5-314), Cleveland, Ohio 44195, USA

(Correspondence should be addressed to W W de Herder; Email: w.w.deherder@erasmusmc.nl)

Endocrine-Related Cancer (2012) 19 E5-E7

The interaction of genomic variation with the microand macro-environment is believed to result in the phenotype, including disease manifestation. It is ironic that the genomic variation that has evolutionarily sustained populations exposed to long periods of famine and has been selected for is now interacting with 'modern' environments and may no longer result in a survival advantage. Au contraire, this genomic variation likely predisposes to obesity and type 2 diabetes mellitus (T2DM), and over recent years has been shown to take on a new bedfellow: cancer.

In adults, obesity is defined as a body mass index (BMI) $>30$. A recent study demonstrated that the widely applied BMI formula $(B M I=$ weight in pounds/(height in inches $)^{2} \times 703 ; \mathrm{BMI}=$ weight in kilograms/(height in meters) ${ }^{2}$ ), which was developed by Lambert Adolphe Jacques Quetelet (1796-1874), underestimates the prevalence of obesity, especially when compared to a direct measurement of percentage body fat by dual-energy X-ray absorptiometry! (Shah \& Braverman 2012). An adjusted, more appropriate definition for obesity of BMI $>24$ in females and $>28$ in males was, therefore, proposed (Shah \& Braverman 2012).

Worldwide, $\sim 475$ million people are obese. The National Health and Nutrition Examination Survey (NHANES), which tracks the prevalence of obesity in the United States over time, shows a significant increase in obesity with prevalence rates currently exceeding $30 \%$ in a majority of states in most sex and age groups (Finucane et al. 2011, Ogden et al. 2012).
'Falstaff: You make fat rascals, Mistress Doll.

Doll Tearsheet: I make them?! Gluttony and diseases make them; I make them not.'

\section{William Shakespeare, 2 Henry IV 2.4.37}

Obesity leads to significant morbidity, premature mortality, and impaired quality of life; together with all preventive attempts, it consumes more than $10 \%$ of the health care budget in the western world (Whitlock et al. 2009, Congressional Budget Office 2010). Obesity is associated with an increased incidence of T2DM, cardiovascular disease (hypertension, heart disease, and stroke), sleep apnea, respiratory diseases, nonalcoholic fatty liver disease, and an increased risk of disability (Malnick \& Knobler 2006).

The NHANES data also show a greater than fourfold increase in the T2DM prevalence over the past 30 years (Danaei et al. 2011). Obesity has a strong association with insulin resistance, hyperinsulinemia, and glucose intolerance and may eventually lead to T2DM (Reaven 2011). Among adults with T2DM, severe obesity is now present in one out of every five adults. In a recent meta-analysis, the relative risk of developing T2DM for obese persons, compared with those with normal weight, was sevenfold (Abdullah et al. 2010). It is generally accepted that the increased prevalence of T2DM is in large part due to the increased prevalence of obesity. T2DM has also been associated with premature 
mortality from several cancers, infectious diseases, and degenerative disorders (Seshasai et al. 2011, Florez \& Castillo-Florez 2012). This issue of Endocrine-Related Cancer is dedicated to the global problem of obesity, T2DM, and the management of these two diseases, as well as their relationships with an increased cancer risk.

To set the stage, Manami Inoue and Shoichiro Tsugane discuss the epidemiological evidence for the relation between insulin resistance and cancer (Inoue \& Tsugane 2012). YunFeng Cui and Dana Andersen follow by discussing the complex relationship between T2DM and type 3c DM and pancreatic cancer (Cui \& Andersen 2012). Dara Cohen and Derek LeRoith focus on the role of insulin and the insulin-like growth factor (IGF) in the association between obesity, T2DM, and the risk of cancer and cancer-related mortality (Cohen \& LeRoith 2012). Mathis Grossmann and Gary Wittert discuss the current epidemiological and mechanistic evidence regarding the interactions between metabolic conditions, sex steroids, and prostate cancer risk and management (Grossman \& Wittert 2012). Aimee Varewijck and Joseph Janssen discuss the potential clinical relevance and potential mechanisms behind the activation of the insulin receptor and IGF1 receptor by insulin analogues, and how this activation may be linked to mitogenesis (Varewijck \& Janssen 2012). Roman Vangoitsenhoven, Chantal Mathieu, and Bart van der Schueren discuss the benefits and potentially cancer-promoting risks of using the new incretin-based therapies, dipeptidyl peptidase-4 inhibitors, and glucagon-like peptide 1 receptor agonists for the treatment of T2DM (Vangoitsenhoven et al. 2012).

We hope the readership will enjoy this series of authoritative reviews on this complex and continually unfolding interplay of obesity, diabetes, and cancer.

\section{Declaration of interest}

The authors declare that there is no conflict of interest that could be perceived as prejudicing the impartiality of the research reported.

\section{Funding}

This research did not receive any specific grant from any funding agency in the public, commercial or not-forprofit sector.

\section{References}

Abdullah A, Peeters A, de Court M \& Stoelwinder J 2010 The magnitude of association between overweight and obesity and the risk of diabetes: a meta-analysis of prospective cohort studies. Diabetes Research and Clinical Practice 89 309-319. (doi:10.1016/j.diabres. 2010.04.012)

Cohen DH \& LeRoith D 2012 Obesity, type 2 diabetes, and cancer: the insulin and IGF connection.

Endocrine-Related Cancer 19 F27-F45. (doi:10.1530/ ERC-11-0374)

Congressional Budget Office 2010 How does obesity in adults affect spending on health care? In Economic and Budget Issue Brief, 8 September 2010. Available at: www.cbo.gov/publication/21772.

Cui Y \& Andersen DK 2012 Diabetes and pancreatic cancer. Endocrine-Related Cancer 19 F9-F26. (doi:10.1530/ ERC-12-0130)

Danaei G, Finucane MM, Lu Y, Singh GM, Cowan MJ, Paciorek CJ, Lin JK, Farzadfar F, Khang YH, Stevens GA et al. 2011 National, regional, and global trends in fasting plasma glucose and diabetes prevalence since 1980: systematic analysis of health examination surveys and epidemiological studies with 370 country-years and 2.7 million participants. Lancet 378 31-40. (doi:10.1016/ S0140-6736(11)60679-X)

Finucane MM, Stevens GA, Cowan MJ, Danaei G, Lin JK, Paciorek CJ, Singh GM, Gutierrez HR, Lu Y, Bahalim AN et al. 2011 National, regional, and global trends in body-mass index since 1980: systematic analysis of health examination surveys and epidemiological studies with 960 country-years and 9.1 million participants. Lancet 377 557-567. (doi:10.1016/S01406736(10)62037-5)

Florez H \& Castillo-Florez S 2012 Beyond the obesity paradox in diabetes: fitness, fatness, and mortality. Journal of the American Medical Association 308 619-620. (doi:10.1001/jama.2012.9776)

Inoue M \& Tsugane S 2012 Insulin resistance and cancer: epidemiological evidence. Endocrine-Related Cancer 19 F1-F8. (doi:10.1530/ERC-12-0142)

Grossman M \& Wittert G 2012 Androgens, diabetes and prostate cancer. Endocrine-Related Cancer 19 F47-F62. (doi:10.1530/ERC-12-0067)

Malnick SD \& Knobler H 2006 The medical complications of obesity. Quarterly Journal of Medicine 99 565-579. (doi:10.1093/qjmed/hcl085)

Ogden CL, Carroll MD, Kit BK \& Flegal KM 2012 Prevalence of obesity in the United States, 2009-2010. National Center for Health Statistics Data Brief 82 1-8.

Reaven GM 2011 The metabolic syndrome: time to get off the merry-go-round? Journal of Internal Medicine 269 127-136. (doi:10.1111/j.1365-2796. 2010.02325.x)

Seshasai SR, Kaptoge S, Thompson A, Di Angelantonio E, Gao P, Sarwar N, Whincup PH, Mukamal KJ, Gillum RF, Holme I et al. 2011 Diabetes mellitus, fasting glucose, 
and risk of cause-specific death. New England Journal of Medicine 364 829-841. (doi:10.1056/ NEJMoa1008862)

Shah NR \& Braverman ER 2012 Measuring adiposity in patients: the utility of body mass index (BMI), percent body fat, and leptin. PLoS ONE 7 e33308. (doi:10.1371/journal. pone.0033308)

Whitlock G, Lewington S, Sherliker P, Clarke R, Emberson J, Halsey J, Qizilbash N, Collins R \& Peto R 2009 Body-mass index and cause-specific mortality in
900000 adults: collaborative analyses of 57 prospective studies. Lancet 373 1083-1096. (doi:10.1016/S01406736(09)60318-4)

Vangoitsenhoven R, Mathieu C \& Van der Schueren B 2012 GLP1 and cancer: friend or foe? Endocrine-Related Cancer 19 F77-F88. (doi:10.1530/ERC-12-0111)

Varewijck AJ \& Janssen JA 2012 Insulin and its analogues and their affinities for the IGF1 receptor. Endocrine-Related Cancer 19 F63-F75. (doi:10.1530/ ERC-12-0026) 